\title{
Does Charity Begin at Home? National Identity and Donating to Domestic Versus International Charities
}

\author{
David John Hart ${ }^{1}$ (D) Andrew Robson ${ }^{1}$
}

Published online: 15 March 2019

(C) The Author(s) 2019

\begin{abstract}
Despite the increased social significance currently attached to national identity, little is known about how national group attachment may correlate with the decision to donate to domestic versus international charities. The current study brings together literature on national identity and charitable giving to empirically validate a model of charitable ethnocentrism and cosmopolitanism. The substantive study is based on an online survey administered to a sample of 1004 UK respondents. The findings indicate that internationalism leads to an increased preference for international charities and a negative inclination towards domestic alternatives. Conversely, nationalism leads to a preference for domestic charities, but a surprisingly non-significant view on international causes. This study adds to the limited empirical research on charitable choice, specifically international giving, and has implications for fundraisers of both domestic and international charities. The work also provides valid and reliable scales for the assessment of charitable ethnocentrism and charitable cosmopolitanism.
\end{abstract}

Keywords National identity - Charitable giving . Charitable ethnocentrism - Charitable cosmopolitanism

David John Hart

david.hart@northumbria.ac.uk

Andrew Robson

andrew.robson@northumbria.ac.uk

1 Newcastle Business School, Northumbria University, Newcastle upon Tyne NE1 8ST, England, UK

\section{Introduction}

Much is known about the broader determinants of charitable giving (best reconciled by Bekkers and Wiepking 2011a). However, such research has come at the expense of understanding charitable choice (Andorfer and Otte 2013; Breeze 2013) and in particular what drives international charity donations (Wiepking 2010). Donors do not share their generosity equally (Strombach et al. 2014), with data from both Europe and North America demonstrating that donors prioritise domestic over international causes (Casale and Baumann 2015; Micklewright and Schnepf 2009). This suggests a level of truth in the old adage that "charity begins at home" (Havens et al. 2006).

Stevenson and Manning (2010) have previously acknowledged that membership of national groups may relate to charitable giving. It has been argued that donors feel greater empathy towards beneficiaries they personally identify with (Einolf et al. 2013). Such a "sense of fit" (Sargeant and Woodliffe 2007) with beneficiaries may arise from nationality, one of the strongest forms of ingroup attachment (Schatz et al. 1999). As such, national identity (defined as feelings of closeness and affection towards one's nation: Blank et al. 2001), offers some conceptual promise. It is posited here that the level of care and attachment felt towards one's nation (which we will operationalise through the constructs of nationalism and internationalism) will relate to one's support of domestic and international charities. As noted by Schons et al. (2015), supporting domestic charities indicates a belief that "compatriots take priority", which contrasts strongly with harbouring equal concern for all of humanity and allocating money to international charities accordingly. We term these opposing positions "charitable ethnocentrism" and "charitable cosmopolitanism", respectively. 
The aim of this study is to empirically validate a model that brings together the previously disparate strands of national identity and domestic versus international charity choice. Utilising a sample of 1004 respondents, the study investigates the extent to which national identity relates to preferences for domestic and international charities. In doing so, we respond to previous calls for further interdisciplinary research into charitable donations (Bekkers and Wiepking 2011a) with specific focus on the underresearched field of international giving (Casale and Baumann 2015). The findings of this study have the potential to inform future academic work on charitable giving as well as the fundraising strategies adopted across an increasingly competitive third sector.

This paper proceeds by utilising extant literature to develop a conceptual model for charitable ethnocentrism and cosmopolitanism. From here, we introduce a survey methodology and present results from a nationally representative UK sample, with the data generated assessing the conceptual model presented by means of a confirmatory factor analysis (CFA) and structural equation modelling (SEM). The paper closes with a discussion of key findings and implications for third sector fundraisers.

\section{Donating to Domestic Versus International Causes}

Distinguishing between charities based upon the location of beneficiaries is an issue of geographical scope or donor proximity (Grau and Folse 2007). Classifying charities as either domestic or international is a common binary used by donors when distinguishing between causes (Breeze 2013; Cheung and Chan 2000). The domestic category encapsulates both local and national level charities, which often have overlapping purposes and beneficiaries (Hall et al. 2013).

Donors feel a moral obligation to assist co-nationals (Stevenson and Manning 2010), which should lead to increased donations for domestic causes (Einolf et al. 2013). The idea that donor preferences may be driven by membership of and attachment to national groups aligns closely with notions of national identity. In contrast, donating to international charities suggests an obligation that extends beyond national boundaries (Dalton et al. 2008). Donations to an international cause are unlikely to provide any direct consumption value to the donor, as they are unlikely to personally benefit or see the outputs of their contribution overseas (Ribar and Wilhelm 1995; Casale and Baumann 2015).

The determinants of international giving remain underresearched (Rajan et al. 2009). International donors are likely to have travelled extensively (Dalton et al. 2008) and come from more educated and politically liberal neighbourhoods (Ribar and Wilhelm 1995). Whilst decisions between domestic versus international causes are mediated by perceived severity of need (Bekkers 2010), a person's sense of obligation to help may weaken as distance from home increases. Whilst this does not preclude helping overseas charities, it does suggest "an order for providing help" (Dalton et al. 2008, p. 500) which sees domestic causes take priority. Little wonder then that majority of people do not donate to international charities, and those that do are also more likely to support domestic causes (Micklewright and Schnepf 2009).

In this study, we develop two constructs that represent an individual's support for domestic versus international charities. These are based upon the broader sociological construct of ethnocentrism, which concerns a placement of one's in-group at the centre of global affairs and a negative disposition towards anything non-domestic (Shankarmahesh 2006). Firstly, we use the term "charitable ethnocentrism" to explain "an individual's preference to support charities that serve beneficiaries within their own nation or national group" (Hart 2016, p. 140). Charitably ethnocentric individuals believe it is wrong to assist other countries when fellow nationals need assistance, and will primarily base their charitable choices on donor proximity (Grau and Folse 2007). Solicitations from international charities may be given consideration, but are likely to be perceived as of secondary importance.

Conversely, "charitable cosmopolitanism" describes a predisposition to favour charities that serve international as opposed to domestic causes. When selecting charities to support, those displaying high charitable cosmopolitanism place greater emphasis on severity of need than the geographical location or nationality of beneficiaries, and may actively search out charities that assist less economically developed countries. As such, their primary concern is the welfare of all individuals with no priority awarded based upon national group membership. Whilst we regard the above two constructs as conceptually distinct, they are not to be deemed polar opposites. As evidenced by Micklewright and Schnepf (2009), those who donate to international charities are also more likely than average to donate to domestic causes, and those who adopt the "charity begins at home" mantra may also assist international charities once they perceive home causes have been sufficiently supported (Dalton et al. 2008).

\section{National Identity}

Feelings of attachment to one's country may alter based upon external prompts such as economic uncertainty or conflict (Leslie et al. 2013). Within the established national identity literature, nationalism and internationalism appear 
to be particularly relevant constructs when exploring the distinction between domestic and international charity support, with both being "centered around one's general attitude towards his/her country and those towards other countries" (Balabanis et al. 2001, p. 158). Some authors have also identified patriotism as a further construct relevant to national identity; however, many studies have found this to be strongly correlated with nationalism (such as a seminal paper in this field by Kosterman and Feshbach 1989). Consequently, much empirical work uses the terms interchangeably (Lee et al. 2003). In this paper, we will focus upon nationalism because of its clear emphasis on national superiority and ethnocentric tendencies.

\section{Nationalism}

Nationalism is seen as an intense form of attachment that is characterised by a belief in superiority and desire to dominate other nations (Federico et al. 2005). This describes a more deep-seated, prejudicial belief in one's country as distinctive and can be viewed as a form of national fanaticism (Van Hooft 2009). Nationalism results in exaggerated self-images of the country, greater support for trade protectionism (Shoham et al. 2006), a desire to preserve the purity of one's country (Dekker et al. 2003) and can result in excessive levels of commitment in times of conflict (Bonikowski 2016).

\section{Internationalism}

This dimension describes "emotional support for international sharing and welfare, and empathy for the peoples of other countries" (Lee et al. 2003, p. 492). Internationalists have a pro-active interest in other nations (Tsai et al. 2013), regard themselves as global rather than national citizens and are willing to cooperate to resolve global problems (Crowson 2009). They display greater levels of admiration for other countries (Shoham et al. 2006) and are more likely to purchase foreign products as a means of supporting third world welfare (Balabanis et al. 2001). Such a concern for the welfare of all humankind rather than merely one's own country reflects an extended form of moral obligation (Delanty 2014) that has clear potential to influence donor decision making.

How will the above dimensions effect charitable giving? Previous research has found that whilst nationalism results in increased consumer ethnocentrism, consumer animosity and perceptions of intergroup differentiation, the reverse was the case for internationalism (Lee et al. 2003; Rosner et al. 2010; Yang et al. 2015). As nationalists display positive in-group attachment, feelings of national pride (Kemmelmeier and Winter 2008) and at times fanatical levels of attachment (Van Hooft 2009), it is hypothesised that nationalism will result in increased charitable ethnocentrism and reduced charitable cosmopolitanism:

$\mathrm{H}_{1}$ : Nationalism has a positive effect on

charitable ethnocentrism

$\mathrm{H}_{2}$ : Nationalism has a negative effect on

charitable cosmopolitanism

As internationalists wish to reduce socio-economic disparity between nations (Rajan et al. 2009) and display broad preferences for foreign products (Parts and Vida 2011), it is predicted that internationalism will have a positive effect on charitable cosmopolitanism. The relationship between internationalism and charitable ethnocentrism is harder to predict, as being an internationalist does not imply anything about an individual's relationship with their own country (Oberecker et al. 2008). As previous work demonstrated that international donors are also more likely to donate to domestic causes (Micklewright and Schnepf 2009), it is predicted that whilst internationalism will lead positively to increased charitable ethnocentrism, the relationship will be weaker than it is towards charitable cosmopolitanism:

$\mathrm{H}_{3}$ : Internationalism has a positive effect on

charitable cosmopolitanism

$\mathrm{H}_{4}$ : Internationalism has a positive effect on

charitable ethnocentrism

In these relationships, it is assumed that the independent variables are nationalism and internationalism, whilst charitable ethnocentrism and charitable cosmopolitanism represent the dependent variables. Hypotheses $\mathrm{H}_{1}-\mathrm{H}_{4}$ proposed above can be brought together into a single proposed research model (Fig. 1) to represent the proposed relationships between the two independent and two dependent variables. Empirical assessment of this model can therefore be undertaken by means of confirmatory factor analysis and structural equation modelling. Whilst no relationship is explicitly hypothesised between charitable ethnocentrism and charitable cosmopolitanism, it is perhaps reasonable to predict that commitment to one type of cause may come at the expense of the other. Assessment of the inter-construct correlations as part of the CFA will enable further exploration of this issue.

\section{Study Design and Methods of Data Analysis}

\section{Procedure}

An online survey approach was utilised to address the stated hypotheses outlined in the conceptual model (Fig. 1). The online approach was used in both the pilot and substantive study. For both the pilot and substantive 
Fig. 1 Conceptual model for charitable ethnocentrism and cosmopolitanism

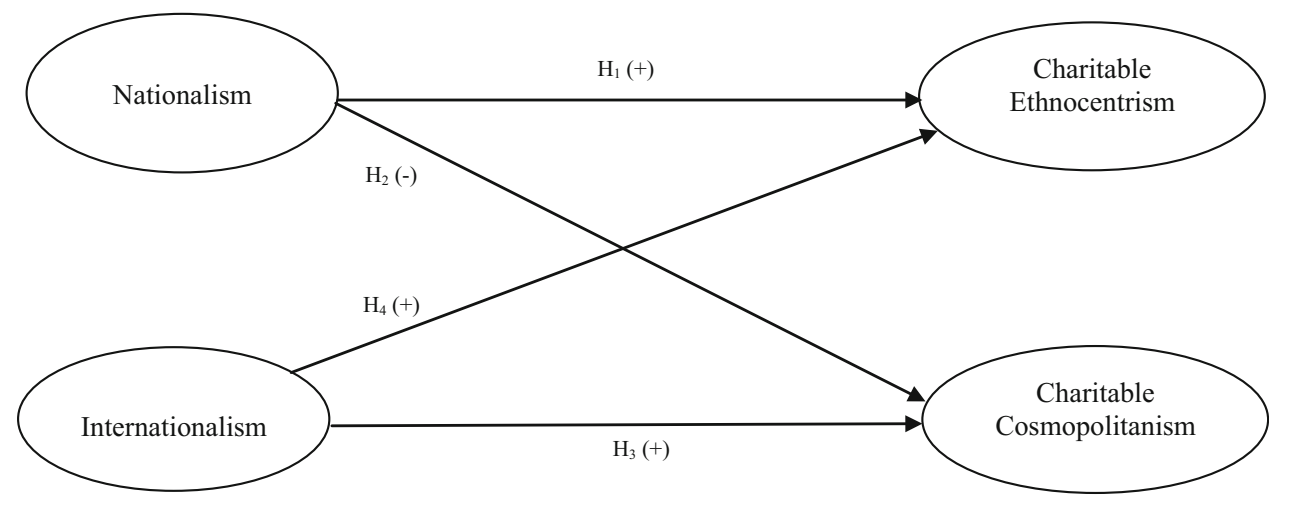

stages of the study, the author's University ethical guidelines were fully adhered to with participant anonymity and confidentiality declared and guaranteed.

\section{Stage 1: Pilot Study}

Prior to data collection in the substantive part of this research, an online pilot survey was undertaken to assess the reliability and validity of the four constructs presented in this study. The aim of a pilot is not to reach a representative sample, but to target up to 100 individuals who form a part of the target population for the overall survey (Rose et al. 2015). The pilot survey was conducted online to ensure this platform was suitable and allowed respondents to add qualitative comments on ease of use and clarity of questions (Blumberg et al. 2014). The pilot survey was distributed electronically to 250 personal contacts via the social network LinkedIn (all of whom met the broad criteria of the overall survey by being based in the UK and over 18 years of age).

Constructs were operationalised through a suite of seven-point Likert scales ( 7 = "Strongly Agree" through to 1 = "Strongly Disagree"), requiring respondents to indicate their level of agreement with a range of statements. Items for nationalism and internationalism coalesced as one ostensible measure to avoid respondent acquiescence and ensure respondents do not artificially understate nationalistic tendencies (Rosner et al. 2010). Likewise, the assessment of charitable choice included a section of randomised items across both charitable ethnocentrism and cosmopolitanism.

\section{Nationalism}

Five items were adapted from Kosterman and Feshbach (1989). Items here addressed perceived superiority over other nations (Kemmelmeier and Winter 2008).

\section{Internationalism}

A battery of nine items from Kosterman and Feshbach (1989) were adapted to assess internationalism. Items here captured a desire to promote international sharing and welfare (Lee et al. 2003) and an empathy with other nations (Balabanis et al. 2001).

\section{Charitable Ethnocentrism \\ and Charitable Cosmopolitanism}

To assess preferences for domestic versus international charities, a battery of new items was developed following the procedures recommended by Churchill (1979). Firstly, a review of existing measures of the broader construct of consumer ethnocentrism was undertaken (including the seminal work of Shimp and Sharma 1987). This review identified that ethnocentrism represents a form of domestic country bias (Zeugner-Roth et al. 2015) and results in negative evaluations of non-domestic products and services (Carpenter et al. 2013). Such measures are based on economic motivations for ethnocentrism (i.e. a desire to protect the domestic economy and employment), which seem less applicable to the context of charitable giving and as such justify the development of a new battery of items.

Utilising existing literature on charitable giving, national identity and consumer ethnocentrism, a battery of items was generated and shared with both fellow academics and a range of third sector organisations (including the Charity Commission for England and Wales, Charity Commission for Northern Ireland, Office of the Scottish Charity Regulator and the Charity Finance Group) prior to the pilot study to ensure face validity. Items for charitable ethnocentrism included "It is wrong to donate to other countries when people in our own country need help" whilst charitable cosmopolitanism items included "I actively choose charities that help people in other parts of the world". The resulting pilot process allows for empirical assessment leading to factor definition; associated item content and post hoc evaluation of construct reliability. 
Analysis

A separate assessment of national identity and charitable preference was undertaken by means of an exploratory factor analysis (EFA). Without setting any a priori hypotheses, the EFA undertaken using SPSS, based on Principal Axis Factoring, considered a Varimax rotation for the two analyses. This therefore assumed no relationships within the two intra-group set of factors, this being subsequently assessed as part of Stage 2 of the study through confirmatory factor analysis. Whilst the standard Kaiser criterion (based on factors with an eigenvalue greater than 1) is typically adopted for factor extraction within an EMA, there is recognition that this may produce a greater than expected or desired number of factors. Instead, the number of factors was set as two for national identity and two for charitable preference based on the development of scales and items as presented above. The Kaiser-Meyer-Olkin (KMO) test and Bartlett's Test of Sphericity were used in both cases for the assessment of factorability.

As part of the iterative approach to assessment, items were potentially removed from the rotated factors based on one or both of low loadings or miss-specification. The defined factors with their item composition were further assessed using Cronbach's alpha coefficients as a post hoc assessment of factor reliability, with the potential for further item reduction within the specified factors to maximise internal reliability. In addition, pilot participants were also requested to provide feedback around the wording and clarity of the items used within the survey instrument, and this feedback was used alongside the quantitative analysis to inform further instrument development ahead of the substantive study. Details of this assessment are reported below and the resultant revised scales and items presented in Table 1.

\section{Data Analysis and Outcomes: Stage 1}

The pilot survey received a total of 112 completed responses (a response rate of 44.8\%: a further 8 responses were incomplete and thus not included in the analysis). The sample reported as $51 \%$ female, with a modal age grouping of 35-44 and modal income of $£ 20,001-30,000$, statistics which closely align with the respondents in our substantive study (stage 2).

\section{National Identity}

The KMO statistic with a value of 0.829 (above 0.8 ) and the significance of Bartlett's Test $\left(X^{2}=655.22, d f=91\right.$, $\operatorname{sig}=0.000)$ confirmed data factorability. The 14 randomised items were allocated to three independent rotated factors whose extraction explained $60.84 \%$ of the data variance, based on initial application of the Kaiser Criterion. The eigenvalue for the third factor of little above 1 (and supported visually by the elbow on the associated Scree Plot showing a degree of "leveling off") suggested a re-run stipulating the extraction of two factors.

For the second run prescribing two factors, the first extracted factor on rotation was identifiably loaded to nine of the variables connected to internationalism, with two measures "I would not be willing to decrease my living standard by $10 \%$ to increase that of persons in poorer countries" and "The alleviation of poverty in other countries is their problem not ours" (0.484) exhibiting low loadings (0.329 and 0.484 , respectively). A third variable "Countries needing our agricultural surpluses should pay for them instead of getting something for nothing" exhibits both a low loading with this factor (factor 1) and factor 2 below ( 0.406 and -0.455 , respectively), hence leading to its elimination. Eliminating these three variables improves the post hoc assessment of internal reliability of the factor using Cronbach's alpha, from 0.863 to 0.877 , to provide a construct comprising six items.

The second extracted factor was loaded to the group of variables that are defined as nationalism. Post hoc assessment for internal reliability on the five retained items provides an alpha coefficient of 0.781 (between 0.7 and 0.8 ), which suggests a reasonably high level of internal reliability that cannot be improved further.

\section{Charitable Choice}

Initially, 11 items were developed to assess charitable choice. As part of an initial pilot assessment involving the third sector, the item "International charities do more important work than charities based in the United Kingdom" was removed prior to the full pilot. Feedback from several pilot respondents had indicated that the item was more concerned with comparing acuteness of need in different parts of the world (a concept explored elsewhere by Cheung and Chan 2000, amongst others). The subsequent EFA was based on the remaining 10 randomised items.

The KMO statistic with a value 0.803 (i.e. above 0.8 ) and the significance of Bartlett's Test $\left(X^{2}=496.80, d f=\right.$ $45, \operatorname{sig}=0.000)$ again confirmed data factorability. The 10 randomised items were allocated to three independent rotated factors whose extraction explained $71.96 \%$ of the data variance, again based on initial application of the Kaiser Criterion. Like the previous EFA, the eigenvalue for the third factor of little above 1, resulting in a reallocation of the items in a rotated solution to two factors $(58.80 \%$ of the variance explained).

The first of the two extracted factors comprised six loaded variables whose commonality aligns to the assessment of charitable preference towards the UK 
Table 1 Scales and constituent items adopted in the substantive study

\section{Charitable ethnocentrism}

CE1: I want my charitable donations to help people in my own country rather than other countries

CE2: It is wrong to donate to other countries when people in our own country need help

CE3: When it comes to donations I believe that "charity begins at home"

CE4: People should help others in their own country before helping people from other countries

Charitable cosmopolitanism

$\mathrm{CC} 1$ : I am likely to donate to a charity that helps other countries in the next month

$\mathrm{CC} 2$ : I actively choose charities that help people in other parts of the world

CC3: International charities provide help to people who need it the most

CC4: I feel better about myself when I give to a charity that focuses on helping other countries

\section{Internationalism}

INT1: If necessary, we ought to be willing to lower our standard of living to cooperate with other countries in getting an equal standard for every person in the world

INT2: We should be more willing to share our wealth with other nations, even it if does not necessarily coincide with our political interests

INT3: We should teach our children to uphold the welfare of all people everywhere even though it may be against the best interests of our own country

INT4: Children should be educated to be internationally minded - to support any movements which contribute to the welfare of the world as a whole, regardless of specific national interests

INT5: The agricultural surpluses of all countries should be shared with poorer people around the world

INT6: UK citizens should assess an international issue based on how much good it does for people across the world, regardless of their nation Nationalism

NAT1: The UK's history makes me feel proud

NAT2: The fact that the UK is the number one state in Europe makes me feel proud

NAT3: Due to the UK's economic superiority, we rightly dominate international decisions

NAT4: For me, the UK is the best state in the world

NAT5: The UK should be used as a role model for other nations

(charitable ethnocentrism). The final two loaded variables, "I am likely to donate to a charity that helps my local community in the next month" and "I feel better about myself when I give to a charity that focuses on helping my country" had a relatively low loadings of 0.449 and 0.416 , respectively, and this, alongside the post hoc assessment of factor reliability led to their removal and improvement of the associated alpha coefficient from 0.825 to 0.888 for the resultant four-item scale.

To complement factor 1 , the four variables loading to the second extracted factor are common to donor commitment to concerns outside of the UK, leading to the label charitable cosmopolitanism. The post hoc assessment for this factor of 0.541 could be improved to 0.754 with the removal of the item "I feel better about myself when I give to a charity that focuses on helping other countries". However, we chose to retain a 4-item scale for the subsequent substantive study, with further refinement of one item to improve post hoc assessment. Specifically, feedback from the pilot study led to amendment of "I select charities based upon on their need rather than what part of the world they help", which was amended to "International charities provide help to people who need it the most" (Item CC3 on the presented scale in Table 1) to ensure clear alignment to the charitable cosmopolitanism construct.

The four retained factors from Stage 1 of the study comprised between four and six items, thereby meeting the minimum requirement advised by Hair et al. (2010) of three items per construct to support a confirmatory factor analysis. The assessment and amendments made here permit evaluation of the model in Fig. 1 and the related hypotheses $\mathrm{H}_{1}-\mathrm{H}_{4}$ within the substantive study.

\section{Stage 2: Substantive Study}

\section{Participant Selection}

All participants were resident in the UK (England, Northern Ireland, Scotland and Wales). The survey, housing the revised scales and items presented in Table 1, was distributed via an established and nationally representative consumer panel, ensuring a balanced sample across demographic criteria such as age, gender and education level. Such factors have been demonstrated to be associated with donation behaviour (Mainardes et al. 2016). The 
intention of this process is to generate a donor sample that is broadly representative of the UK population. In addition to assessing the various constructs within the study, the survey also included questions on the respondent's wider giving behaviour, including number of charities supported and preferred donation channels.

\section{Analysis}

Data from the substantive study are analysed using confirmatory factor analysis (CFA) and structural equations modelling (SEM), an approach widely recommended for model validation and structural relationship assessment (Hair et al. 2010; Tabachnick and Fidell 2013). Analysis was undertaken with parallel applications of SPSS and AMOS. For part one of this combined assessment, the measurement model is assessed for validity, reliability and goodness of fit using CFA. Various long-established goodness-of-fit measures are employed, including the normed Chi-squared $\left(X^{2} / d f\right)$, Goodness of Fit Index (GFI), Comparative Fit Index (CFI), Tucker-Lewis Index (TLI) and the Root-Mean-Square Error of Approximation (RMSEA) statistic for the assessment of model error. For part two, development of a SEM is required to assess the conceptual model and quantify the model paths represented by hypotheses $\mathrm{H}_{1}-\mathrm{H}_{4}$. This quantitative assessment is based on the Maximum Likelihood method of estimation, given its appropriateness for data characterised by limited issues related to Normality.

\section{Data Analysis and Findings: Stage 2}

Data collection took place during March 2017, utilising a consumer panel accessed through market research firm Pickersgill Consultancy and Planning, allowing the survey to target a nationally representative sample. The sampling frame for this survey was any individual who has previously signed up to take part in online surveys via consumer panels, and met our participation criteria of being over 18 years of age and resident in the UK. In return for their participation, panel members receive points which can be redeemed for shopping vouchers. A quota sampling process was utilised here to ensure that the sample was broadly representative of the wider population based upon age, gender and ethnicity. The survey was emailed out to members of the consumer panel until our quotas were reached, at which point the survey was closed. A total of 1141 responses were received, with 137 removed owing to either incompletion, missing data or straight-lining (where a respondent continually gives the same scale answer across all questions). A length of completion check was also undertaken on all respondents to ensure that surveys were not completed so quick as to potentially compromise the validity of the data.

The end result was a fully complete dataset of 1004 respondents, with the demographic profile presented in Table 2. An assessment of the sample characteristics with the wider UK population is presented here, with certain significant differences reported at the $0.1 \%$ level. The sample reported comprises $51.7 \%$ female, $92 \%$ white, with a relatively equal spread of respondents across age groups. Gender matches closely with UK census data which identified the population at $50.7 \%$ female. Responses from the BME participants $(8 \%)$ were significantly under-represented compared to UK census data (14\%: ONS 2017). Almost half of the survey respondents live in England (49.8\%), with Wales (20.2\%), Scotland (19.9\%) and Northern Ireland $(10.1 \%)$ also well represented (this was artificially weighted to allow for a reasonable number of respondents from each country, and is therefore statistically different from the UK population in its entirety). The modal salary bands were $£ 10,001-20,000$ (27.4\%) and $£ 20,001-30,000$ (22.6\%), with the most common forms of employment being junior management (25\%) and skilled manual (20\%), again broadly consistent with census data (ONS 2017). Just over half $(51.2 \%)$ reported voting leave in the 2016 UK EU membership referendum, almost identical to the official results $(51.8 \%$ leave: Electoral Commission 2018).

For the sample, $80.6 \%$ have made charitable donations within the last three months (compared to $89 \%$ of the UK population according to the Charities Aid Foundation 2017), with the modal donation being $£ 11-20$ (17.5\%). The most common means of giving were donating to charity shops $(76.5 \%)$ and cash donations (69.6\%), which mirrors data from the Charities Aid Foundation (2017). Based on the above data, there appears ample evidence to suggest that our respondents resonate with the wider UK population in terms of donation channels but are slightly more reluctant in terms of actual donations.

With the range of demographic measures considered, there is justification for a level of cautious optimism about the sample which is large in absolute terms, and across specific demographics is representative of the wider UK potential donor population (notwithstanding particular divergence on UK country, ethnicity and intention to donate). This represents a relatively favourable sampling outcome. In their recent assessment of charitable giving, Knowles and Sullivan (2017) provide a candid assessment of the challenges presented in ensuring a voluntary, random sample is representative of its parent population and is sufficiently large in absolute terms. The data generated in this study by means of quota sampling are arguably more representative to its setting than that generated by the 
Table 2 Sample characteristics and comparison with the UK population

\begin{tabular}{|c|c|c|c|c|c|}
\hline Measures & No. participants & $\%$ participants $(\%)$ & UK population (\%) & $t$ score & Significance level \\
\hline All persons & 1004 & & & & \\
\hline Males & 485 & 48.3 & 49.3 & -0.634 & 0.526 \\
\hline Females & 519 & 51.7 & 50.7 & 0.634 & 0.526 \\
\hline \multicolumn{6}{|l|}{ Age-band } \\
\hline $18-24$ & 86 & 8.6 & 8.3 & 0.345 & 0.730 \\
\hline $25-34$ & 166 & 16.5 & 17.7 & -0.996 & 0.319 \\
\hline $35-44$ & 168 & 16.7 & 16.5 & 0.171 & 0.864 \\
\hline $45-54$ & 190 & 18.9 & 18.3 & 0.492 & 0.623 \\
\hline $55-64$ & 157 & 15.6 & 15.4 & 0.176 & 0.861 \\
\hline 65 and over & 237 & 23.6 & 23.7 & -0.075 & 0.941 \\
\hline \multicolumn{6}{|l|}{ Ethnicity } \\
\hline White & 924 & 92.0 & 86.0 & 5.479 & 0.000 \\
\hline BME groups & 80 & 8.0 & 14.0 & -5.479 & 0.000 \\
\hline \multicolumn{6}{|l|}{ Country } \\
\hline England & 500 & 49.8 & 84.2 & -29.884 & 0.000 \\
\hline Northern Ireland & 101 & 10.1 & 2.8 & 14.021 & 0.000 \\
\hline Scotland & 200 & 19.9 & 8.2 & 13.512 & 0.000 \\
\hline Wales & 203 & 20.2 & 4.7 & 23.206 & 0.000 \\
\hline \multicolumn{6}{|l|}{ EU referendum vote } \\
\hline Remain & 500 & 49.8 & 49.2 & 0.380 & 0.704 \\
\hline Leave & 514 & 51.2 & 51.8 & -0.380 & 0.704 \\
\hline \multicolumn{6}{|l|}{ Donation intention } \\
\hline Yes & 809 & 80.6 & 89.0 & -8.507 & 0.000 \\
\hline
\end{tabular}

UK Population Data provided by Electoral Commission 2018; ONS 2017)

Knowles and Sullivan (2017) research based in New Zealand.

In terms of charitable preference, the respondents were more predisposed to charitable ethnocentrism than for charitable cosmopolitanism, as demonstrated by the percentage frequency distributions and mean scores for the items presented in Table 3. For charitable ethnocentrism, the modal response for each item was "neither agree nor disagree", but a greater proportion of the donors responded positively to each item compared with those exhibiting negativity, giving a range of mean item scores on the 7 -point scales from 4.50 to 5.03. For the items relating to charitable cosmopolitanism, the modal response across the items was also "neither agree nor disagree", but conversely, a greater proportion of the donors responded negatively to three of the four presented items, giving a range of mean item scores from 3.45 to 4.13 .

The literature has consistently evidenced the impact of various demographic factors on donation behaviours (for example, Leslie et al. 2013; Piff et al. 2010; Willer et al. 2015 and usefully summarised by Bekkers and Wiepking 2011b). Consequently, the aim of this paper was not to explore the influence of demographic factors on charitable giving. However, it is useful to assess if any of the constructs utilised in our structural model appear to be influenced by factors such as gender, age, nationality and ethnicity. Our analysis suggests that there are very few significant differences by gender for both nationalism and internationalism. In terms of age, some individual items demonstrate differences across both dimensions of national identity; levels of internationalism tend to be higher amongst younger survey respondents, whilst nationalism tends to increase gradually increase until it peaks at the 45-54 age group. Relatively stronger levels of agreement for nationalism were identified in those respondents from England, with the Northern Ireland sample scoring higher in terms of internationalism. Limited differences appear for nationalism by ethnicity, although the study participants from the various minority ethnic groupings (a very small proportion of our overall sample) appear more predisposed to internationalism.

With these differences, however, limited, there is an argument that the model presented could be adapted further to incorporate the moderating effects of demographics on nationalism and internationalism as antecedents to charitable ethnocentrism and charitable cosmopolitanism. There 
Table 3 Summary statistics for charitable ethnocentrism and charitable cosmopolitanism

\begin{tabular}{|c|c|c|c|c|c|c|c|c|}
\hline & \multicolumn{7}{|l|}{ Score } & \multirow[t]{2}{*}{ Mean } \\
\hline & 7 & 6 & 5 & 4 & 3 & 2 & 1 & \\
\hline \multicolumn{9}{|l|}{ Charitable ethnocentrism } \\
\hline $\begin{array}{l}\text { CE1: I want my charitable donations to help people in my own country } \\
\text { rather than other countries }\end{array}$ & $26.2 \%$ & $17.2 \%$ & $15.3 \%$ & $27.9 \%$ & $5.8 \%$ & $3.1 \%$ & $4.5 \%$ & 5.03 \\
\hline $\begin{array}{l}\text { CE2: It is wrong to donate to other countries when people in our own } \\
\text { country need help }\end{array}$ & $20.2 \%$ & $11.4 \%$ & $14.2 \%$ & $28.4 \%$ & $11.5 \%$ & $6.3 \%$ & $8.1 \%$ & 4.50 \\
\hline CE3: When it comes to donations I believe that "charity begins at home" & $21.1 \%$ & $15.1 \%$ & $18.0 \%$ & $30.5 \%$ & $5.9 \%$ & $3.6 \%$ & $4.8 \%$ & 4.80 \\
\hline \multirow{2}{*}{$\begin{array}{l}\text { CE4: People should help others in their own country before helping people } \\
\text { from other countries }\end{array}$} & $20.1 \%$ & $12.8 \%$ & $16.0 \%$ & $33.1 \%$ & $7.9 \%$ & $3.9 \%$ & $6.2 \%$ & 3.68 \\
\hline & 7 & 6 & 5 & 4 & 3 & 2 & 1 & Mean \\
\hline \multicolumn{9}{|l|}{ Charitable cosmopolitanism } \\
\hline $\begin{array}{l}\mathrm{CC} 1 \text { : I am likely to donate to a charity that helps other countries in the next } \\
\text { month }\end{array}$ & $6.9 \%$ & $8.5 \%$ & $10.6 \%$ & $35.5 \%$ & $9.9 \%$ & $8.9 \%$ & $19.9 \%$ & 3.62 \\
\hline CC2: I actively choose charities that help people in other parts of the world & $4.8 \%$ & $6.4 \%$ & $9.8 \%$ & $36.4 \%$ & $13.5 \%$ & $8.5 \%$ & $20.7 \%$ & 3.45 \\
\hline CC3: International charities provide help to people who need it the most & $7.9 \%$ & $10.7 \%$ & $16.5 \%$ & $40.7 \%$ & $8.8 \%$ & $5.8 \%$ & $9.7 \%$ & 4.13 \\
\hline $\begin{array}{l}\text { CC4: I feel better about myself when I give to a charity that focuses on } \\
\text { helping other countries }\end{array}$ & $5.4 \%$ & $7.7 \%$ & $10.9 \%$ & $47.1 \%$ & $7.3 \%$ & $6.5 \%$ & $15.2 \%$ & 3.77 \\
\hline
\end{tabular}

$7=$ strongly agree, $6=$ agree, $5=$ somewhat agree, $4=$ neither agree nor disagree, $3=$ somewhat disagree, $2=$ disagree, $1=$ strongly disagree

are, however, obvious practical barriers in achieving this with our sample, particularly for ethnicity (where $92 \%$ of the respondents are reported as white and the remainder spread thinly across a range of ethnic groups). With a larger data set and greater representation of these various groupings, the assessment of moderation on these antecedents to charity predisposition is clearly of merit and its exclusion here is an understood limitation of the study.

\section{Sample Sufficiency and Adequacy}

The data collection process ensured there was no missing or wrongly recorded data. Survey data were only used for fully completed surveys (respondents would only receive redeemable points if they responded to all items). As mentioned above, a small number of cases were removed because of straight lining (which may indicate the respondent was not fully considering each item) or the respondent completing the survey in a time deemed to be excessively quick. Data from the survey were coded automatically through the survey software, with random checks undertaken to ensure accuracy. Consequently, there was no need to apply the "complete case approach" or "data imputation" (Hair et al. 2010). The Mahalanobis $D^{2}$ method to assess for multivariate outliers and variable assessment for Normality by means of measuring skewness and kurtosis highlighted no issues, with limited departure from data Normality.

\section{Assessment of CFA}

Assessment of the CFA suggests an appropriate model fit: $X^{2} / d f=4.346$ [Hair et al. (2010) recommends between values between 2 and 5], GFI $=0.914$, TLI $=0.940$, $\mathrm{CFI}=0.949$ (all at least 0.9) and RMSEA $=0.064$ (under 0.08 ). Table 4 also gives an indication of the satisfactory AVE values, with all four exceeding $50 \%$. The four construct reliability coefficients are in excess of 0.8 (as are the Cronbach alpha coefficients for the suite of constructs, thereby endorsing the modifications made as a consequence of the pilot study). Sixteen of the items considered had standardised loadings of at least 0.7 , the remaining three being between 0.6 and 0.7 . The three items with the loadings below 0.7 were INT1- "If necessary, we ought to be willing to lower our standard of living to cooperate with other countries in getting an equal standard for every person in the world" (0.673), INT4- "Children should be educated to be internationally minded-to support any movements which contribute to the welfare of the world as a whole, regardless of specific national interests" (0.646) and NAT3-"Due to the United Kingdom's economic superiority, we rightly dominate international decisions" (0.666). The benchmarks presented here point to a robust structural model, with appropriate levels of reliability and validity, without any removal of the three items with the relatively lower loadings.

For discriminant validity, the AVE for each construct should exceed the respective squared inter-construct 
Table 4 Measures of average variance extracted, construct reliability and standardised item loadings by model iteration

\begin{tabular}{lllll}
\hline Construct & CC & CE & INT & NAT \\
\hline Average variance extracted (AVE) & $65.03 \%$ & $69.93 \%$ & $56.92 \%$ & $61.38 \%$ \\
Construct reliability & 0.881 & 0.903 & 0.816 & 0.888 \\
Cronbach $\alpha$ coefficient & 0.894 & 0.900 & 0.886 & 0.889 \\
No. items & 4 & 4 & 6 & 5 \\
Standardised loadings (range of values) & $0.723-0.883$ & $0.805-0.871$ & $0.646-0.808$ & $0.666-0.834$ \\
\hline
\end{tabular}

There are no further issues with regard to discriminant validity. Of the 19 items remaining, 16 have a standardised loading of at least 0.7 , the other items having a loading value in excess of 0.6 correlations, thereby assuring that the items assessed share greater commonality with their allotted constructs than with others (Table 5). The condition of discriminant validity between the constructs is met for this particular model.

A further interesting feature of this analysis is the relatively strong, negative association $(r=-0.482)$ between the charitable cosmopolitan and charitable ethnocentrism constructs, suggesting greater disposition by the charitable donor for international causes is associated with less enthusiasm for domestic alternatives, and vice versa. Although not included as a formal hypothesis in this study, this does present an interesting finding which challenges the previous suggestion that those who donate to international charities are more likely to also supporting domestic causes (Micklewright and Schnepf 2009).

\section{Assessment of Relationship Paths via SEM}

For the updated model, the fit statistics are $X^{2} / d f=4.558$, $\mathrm{GFI}=0.910, \mathrm{TLI}=0.936, \mathrm{CFI}=0.945$ and $\mathrm{RMSEA}=$ 0.066 (see Fig. 2 and Table 6 for path details).

The path between nationalism charitable cosmopolitanism is negative $(\beta=-0.038, p=0.335)$ and for charitable ethnocentrism the path is strong, positive and statistically significant at the $0.1 \%$ level $(\beta=0.533$, $p=0.000)$. Therefore as nationalism increases so does charitable ethnocentrism, supporting $\mathrm{H}_{1}$. Nationalism does result in decreased charitable cosmopolitanism; however, this path lacks statistical significance and as such $\mathrm{H}_{2}$ is rejected. A strong positive and statistically significant path was identified between internationalism and

Table 5 Inter-construct correlations

\begin{tabular}{lrrrr}
\hline & \multicolumn{1}{c}{ CC } & \multicolumn{1}{l}{ CE } & INT & NAT \\
\hline CC & 0.650 & & & \\
CE & -0.482 & 0.699 & & \\
INT & 0.732 & -0.454 & 0.569 & \\
NAT & 0.025 & 0.452 & 0.058 & 0.614 \\
\hline
\end{tabular}

charitable cosmopolitanism $(\beta=1.067, p=0.000)$, and a strong negative and statistically significant path was identified linking internationalism and charitable ethnocentrism $(\beta=-0.596, p=0.000)$. Both paths are significant at the $0.1 \%$ level, supporting $\mathrm{H}_{3}$ but rejecting $\mathrm{H}_{4}$ given the negative coefficient that has emerged $\left(\mathrm{H}_{4}\right.$ hypothesised a positive relationship). From a marginal perspective, internationalisation represents the stronger of the two antecedents, given path coefficient values and significance levels emerging. The squared multiple correlations $\left(R^{2}\right)$ for the endogenous variables charitable cosmopolitanism and charitable ethnocentrism are 0.557 and 0.456 , respectively, indicating a moderate level of explained variance by the predictor variables nationalism and internationalism.

\section{Discussion}

The study presented here makes a number of important contributions to the field of charitable giving. The primary distinction appears to be between those with a strong affection for their nation (nationalism) and those with a more global mindset (internationalism). The final structural model also makes an important contribution to understanding how both internationalism and nationalism correlate with charitable choice, in both cases in an intuitive (and to some extent counterintuitive) manner.

In an absolute sense, the study further confirms preference for domestic over international causes as shown by the data summary in Table 3 between charitable ethnocentrism and charitable cosmopolitanism (Casale and Baumann 2015; Micklewright and Schnepf 2009). With respect to the antecedents of choice, donors with an internationalist predisposition display higher levels of charitable cosmopolitanism, as expected. Internationalism reflects support and empathy for people suffering across nations (Lee et al. 2003), which translates into support for charities that serve these same beneficiaries. More surprising, however, is the negative relationship between internationalism and consumer ethnocentrism. It had been hypothesised that internationalists would also show positive disposition towards domestic charities as they display care for people 
Fig. 2 Tested model with path coefficients

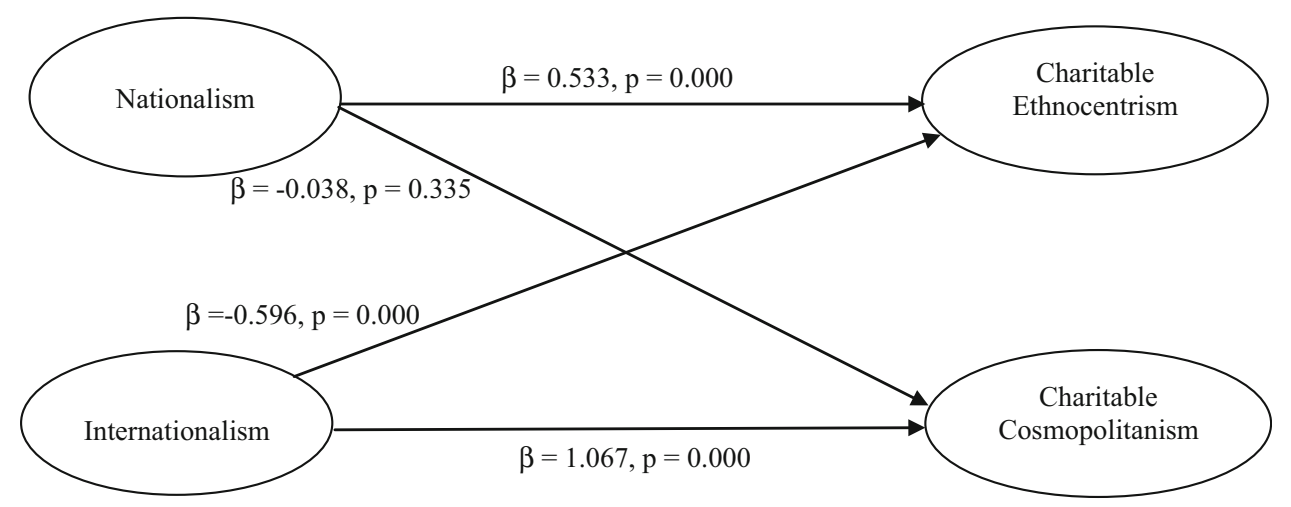

Table 6 Path analysis and summary of retained hypotheses

\begin{tabular}{|c|c|c|c|c|c|}
\hline Hypothesis & Path & Direction & Path weighting & $P$ value & Outcome \\
\hline $\mathrm{H}_{1}$ & Nationalism $\rightarrow$ charitable ethnocentrism & Positive & 0.533 & 0.000 & Supported \\
\hline $\mathrm{H}_{2}$ & Nationalism $\rightarrow$ charitable cosmopolitanism & Negative & -0.038 & 0.335 & Rejected $^{\mathrm{a}}$ \\
\hline $\mathrm{H}_{3}$ & Internationalism $\rightarrow$ charitable cosmopolitanism & Positive & 1.067 & 0.000 & Supported \\
\hline $\mathrm{H}_{4}$ & Internationalism $\rightarrow$ charitable ethnocentrism & Negative & -0.596 & 0.000 & Rejected $^{\mathrm{b}}$ \\
\hline
\end{tabular}

Hypotheses $\mathrm{H}_{3}$ and $\mathrm{H}_{4}$ were not tested given the removal of the Patriotism construct

${ }^{a}$ Rejected on grounds of statistical insignificance

${ }^{\mathrm{b}}$ Rejected on grounds of direction of path

regardless of their nationality (Oberecker et al. 2008). However, it would appear that those with internationalist tendencies are less inclined to support such domestic charities. This interesting finding warrants further investigation. Do internationalists consciously focus their donations on bridging perceived inequalities across nations? Do they believe that severity of need should reign over donor proximity? Or do they avoid some types of national level charity (e.g. military causes who support armed forces veterans) as a form of opposition to military activity that could be perceived as having more nationalistic motives? Given the paucity of research on international giving, further work to understand the motivations behind charitable choice would have significant academic and practical value.

The structural model also provides insights into the relationship between nationalism and charitable giving. Nationalism is positively associated with charitable ethnocentrism and negatively associated with charitable cosmopolitanism, albeit the latter path is insignificant. Nationalists display a clear preference for charities that serve fellow nationals, and as such, represent a viable segment for charities with a clearly demonstrable national purpose (for example, military charities). This is an unsurprising finding given that nationalists desire superiority over other nations and are protectionist in nature (Livi et al. 2014). For a nationalist, supporting a domestic charity is a practical means of alleviating their country's problems.

The hypothesised negative relationship between nationalism and charitable cosmopolitanism was not supported by the data in a statistically significant way. It would appear that whilst nationalists are naturally inclined to support domestic charities, they are not necessarily averse to assisting international causes in the same way that internationalists are opposed to helping domestic charities. This finding suggests there is some scope for international causes to successfully target those with nationalist tendencies. The nationalistic want for superiority over other nations (Kemmelmeier and Winter 2008) may simply translate into prioritising domestic charities as opposed to more aggressive behaviours towards out-groups. Indeed, such individuals may also be willing to donate to global causes that do not compromise their desire for dominance (Blank and Schmidt 2003). For nationalists, it would appear that charity begins at home, but it does not necessarily end there.

Synthesising the above, internationalism represents a marginally stronger predictor of charitable giving compared to nationalism, as presented by the path coefficients presented in Fig. 2 and Table 6. However, both constructs lead to higher levels of charitable cosmopolitanism and charitable ethnocentrism, respectively. This builds on the prior qualitative work on national identity and 
charitable giving by Stevenson and Manning (2010) and provides empirical evidence demonstrating how national identity translates into charitable preferences.

The model itself also makes one further significant contribution in that it presents two statistically valid and reliable constructs and associated items for the assessment of charitable cosmopolitanism and charitable ethnocentrism. In a practical sense, these constructs can assist charities in assessing the priorities of potential donors and nuancing their targeting and fundraising campaigns accordingly.

At this point, it is appropriate to reflect on the nature of items used to assess charitable ethnocentrism and charitable cosmopolitanism, and the potential impact this may have upon the causality of our findings. As evidenced in Table 1, these items assess individual beliefs (e.g. "People should help others in their own country before helping people from other countries" or intentions (e.g. "I am likely to donate to a charity that helps other countries in the next month") as opposed to actual behaviours. However, we retain the belief that the relationships between our independent variables (nationalism and patriotism) and our dependent variables (charitable ethnocentrism can charitable cosmopolitanism) can be viewed as causal in nature. A review of the broader concept of consumer ethnocentrism (concerning the morality of purchasing goods from foreign countries: Shimp and Sharma 1987) demonstrates the multiple studies have followed a similar procedure. The widely utilised CETSCALE (which, like our scale, assessing intentions rather than behaviours) has been used to assess causal relationships with other variables via multiple regression (e.g. Balabanis et al. 2001; Carpenter et al. 2013; Fischer and Zeugner-Roth 2017) or structural equation modelling (e.g. Acharya and Elliott 2003; Altintas and Tokol 2007; Cleveland et al. 2009; Fernández-Ferrín et al. 2015; Yildiz et al. 2018).

One potential limitation in the assessment of donor behaviour and related charitable choice is that the constructs for both Charitable Ethnocentrism and Charitable Cosmopolitanism comprise items that relate explicitly to intention rather than the actuality of donation. Potentially, their statistical linkage is one of association rather than causation. There is evidence from the literature of the relatively strong and significant role played by donation intention as a predictor of behaviour (Smith and McSweeney 2007) and past behaviour serving as a predictor of intention (Knowles et al. 2012). Kashif et al. (2015) provide specific empirical evidence that intention is both a direct and statistically significant antecedent to actual donation behaviour. In the context of this study, to assess the link between intention and actuality, correlation and analysis between Charitable Ethnocentrism and Charitable Cosmopolitanism and recent actual giving (measured through financial donation in the preceding 3 months to the study) suggested only a weak, but negative relationship involving Charitable Ethnocentrism $(r=-0.098$, $p=0.002$ ) but a moderately strong correlation involving Charitable Cosmopolitanism $(r=0.324, p=0.000)$. It is therefore of merit to examine actual donation behaviour through explicit future giving and its links to these domestic and international levels of intention.

\section{Concluding Remarks}

This paper aimed to explore the extent to which national identity may relate to preferences for domestic versus international charity choice. In summary, whereas nationalists favour domestic charities but are not necessarily averse to assisting international causes, internationalists demonstrate strong preferences for global causes and are typically more negative towards domestic causes. The findings demonstrate that nationalist or internationalist tendencies are significant predictors of charitable giving, and as such, add to the limited body of knowledge on understanding charitable choice. For fundraisers, the results suggest that an international charity may be able to successfully target individuals with nationalist tendencies, providing they can demonstrate that any donations do not compromise national interests. Conversely, domestic charities may struggle to convince internationalists to divert their money from overseas causes. A suitable approach here may be to demonstrate how their work has positive consequences both at home and overseas, a strategy utilised by large UK telethons such as Comic Relief.

Future research could focus on those who identify themselves as internationalists, in particular to understand their negative disposition towards domestic charities. For nationalists, understanding their empathy towards helping refugees, be that in their home country or when displaced to other locations, would prove useful for both international aid organisations and political strategists. Charitable ethnocentrism indicates a preference for charities that service fellow nationals, but such national boundaries are constantly blurred by migration. Extension of the current research to other countries with differing political and economic conditions would provide insights into whether the global population buys into the "charity begins at home" mantra. Equally, regional identity (attachment to a local region as opposed to one's country, which may be particularly applicable in countries such as Spain) may offer insights into preferences for more local causes.

The current study focused on donation intentions as opposed to actual giving behaviour. Prior studies have utilised the theory of planned behaviour to demonstrate that donation intentions are a powerful predictor of actual 
giving (Kashif et al. 2015), more so than other antecedents such as moral norms and attitudes (Smith and McSweeney 2007). Future research would benefit greatly from tracking both donor intentions and behaviour over time, specifically to understand if this fluctuates based upon changes in the economic or political environment (that can influence levels of nationalism: Huddy and Khatib 2007).

The relationship between various demographic factors and charitable giving have been widely investigated (Bekkers and Wiepking 2011b, Knowles and Sullivan 2017; Lwin et al. 2014). Whilst the aim of this paper was not specifically to these demographic factors, our data did indicate some statistically significant relationships; younger age groups, women and respondents from Northern Ireland reported higher levels of charitable cosmopolitanism. Interestingly, our wider dataset also suggests that individuals who voted for the UK to leave the European Union in 2016 were significantly more likely to report as charitably ethnocentric, with remain voters in contrast reporting higher levels of charitable cosmopolitanism. Further work in this field could expand on these findings to truly appreciate segments where charitable ethnocentrism and charitable cosmopolitanism are most prevalent, a finding that would prove to be especially relevant to fundraisers seeking to target potential donors efficiently.

One particular demographic issue which is ripe for further exploration is the role of ethnicity in charitable giving. In the current study, our sample of $92 \%$ white respondents meant we were unable to engage in any meaningful comparative analysis owing to the small numbers in the various ethnic minority groups. Given the increased number of migrants across the developed world [2018 net UK migration was estimated at 280,000 (ONS 2018) and in the same period over $1 \mathrm{~m}$ permanent residents arrived in the USA (DHS 2018)], this remains a notable limitation of the current study.

Osili and Du (2005) have previously noted that migrant status has a negative (albeit insignificant) impact on charitable giving. Elsewhere it has been found that donations from different ethnic groups can vary significantly and can be influenced by the ethnic make-up of the local community (Andreoni et al. 2016). For migrants, the sense of local interest that inspires domestic donations (Burgoyne et al. 2005) may be applicable to both home and host cultures, especially if family members are still residing in the home country. Indeed, for migrants who develop dual identities (Glasford and Dovidio 2011; Jacobson 1997), supporting charities in their home country and their host country may both be seen as forms of charitable ethnocentrism. Many migrants will engage in worker remittances (which refers to sending money via bank transfer back to family in their home country: Taylor 1999). In 2016, global remittances were estimated at almost $\$ 450 \mathrm{bn}$, with $55 \%$ of this money directed to Asia and the Pacific region (IFAD 2018). Future work sampling sizeable numbers of ethnic minority groups could explore the role of ethnicity and acculturation on charitable giving, and in particular investigate if the mode of acculturation experienced by migrants (which may include both assimilation and integration: Berry 1980) impacts on their charitable decision making.

In the UK and other developed economies, the role of the state and politics represents an alternative area of consideration. A plethora of government decisions concerning welfare and the economy have "a far reaching impact on the non-profit economy" (Brooks 2004, p. 179). Indeed, charities and governments are difficult to separate because of their overlapping agendas on public service provision (Besemer and Bramley 2012). Policies that appear particularly ripe for research here include austerity (which can result in greater "home-first" sentiment: Flatters and Willmott 2009) and overseas development aid (a contentious area of public spending which may speak volumes for an individual's perspective on inter-country relations (Tsai et al. 2013).

For now though, based on our UK data (and contrary to the old adage), whilst some people believe that charity begins at home but can extend to other countries, others feel that charity begins (and ends) further afield.

Acknowledgements The authors would like to thank the Marketing Trust for their funding of this research project, and Professor Fraser McLeay of the University of Sheffield for his extensive support throughout the process.

Funding This study was funded by the Marketing Trust (no grant number provided).

\section{Compliance with ethical standards}

Conflict of interest The authors declare that they have no conflict of interest.

Open Access This article is distributed under the terms of the Creative Commons Attribution 4.0 International License (http://crea tivecommons.org/licenses/by/4.0/), which permits unrestricted use, distribution, and reproduction in any medium, provided you give appropriate credit to the original author(s) and the source, provide a link to the Creative Commons license, and indicate if changes were made.

\section{References}

Acharya, C., \& Elliott, G. (2003). Consumer ethnocentrism, perceived product quality and choice: An empirical investigation. Journal of International Consumer Marketing, 15(4), 87-115. https://doi. org/10.1300/j046v15n04_05.

Altintaş, M. H., \& Tokol, T. (2007). Cultural openness and consumer ethnocentrism: An empirical analysis of Turkish consumers. Marketing Intelligence \& Planning. https://doi.org/10.1108/ 02634500710754565. 
Andorfer, V. A., \& Otte, G. (2013). Do contexts matter for willingness to donate to natural disaster relief? An application of the factorial survey. Nonprofit and Voluntary Sector Quarterly, 42(4), 657-688. https://doi.org/10.1177/0899764012440 180.

Andreoni, J., Payne, A. A., Smith, J., \& Karp, D. (2016). Diversity and donations: The effect of religious and ethnic diversity on charitable giving. Journal of Economic Behavior \& Organization, 128, 47-58. https://doi.org/10.1016/j.jebo.2016.05.010.

Balabanis, G., Diamantopoulos, A., Mueller, R. D., \& Melewar, T. C. (2001). The impact of nationalism, patriotism and internationalism on consumer ethnocentric tendencies. Journal of International Business Studies, 32(1), 157-175. https://doi.org/10.1057/ palgrave.jibs. 8490943 .

Bekkers, R. (2010). Who gives what and when? A scenario study of intentions to give time and money. Social Science Research, 39(3), 369-381. https://doi.org/10.1016/j.ssresearch.2009.08. 008.

Bekkers, R., \& Wiepking, P. (2011a). A literature review of empirical studies of philanthropy: Eight mechanisms that drive charitable giving. Nonprofit and Voluntary Sector Quarterly, 40(5), 924-973. https://doi.org/10.1177/0899764010380927.

Bekkers, R., \& Wiepking, P. (2011b). Who gives? A literature review of predictors of charitable giving. Part one: Religion, education, age and socialisation. Voluntary Sector Review, 2(3), 337-365. https://doi.org/10.1332/204080511X6087712.

Berry, J. W. (1980). Acculturation as varieties of adaptation. Acculturation: Theory, models and some new findings, 9, 25.

Besemer, K., \& Bramley, G. (2012). Poverty and social exclusion in the UK. ESRC working paper. Available at: http://193.104. 168.102/system/files/WP\%20Analysis\%20No.2\%20-\%20Local\% 20Services\%20Under\%20Siege\%20(Besemer\%20\%20Bramley\% 20May\%202012).pdf. Accessed 1 July 2015.

Blank, T., \& Schmidt, P. (2003). National identity in a United Germany: Nationalism or patriotism? An empirical test with representative data. Political Psychology, 24(2), 289-312. https://doi.org/10.1111/0162-895X.00329.

Blank, T., Schmidt, P., \& Westle, B. (2001). A contradiction, a possibility, or an empirical reality? 'Patriotism'. Paper presented at the European Consortium for Political Research Conference, Grenoble, France.

Blumberg, B. F., Cooper, D. R., \& Schindler, P. S. (2014). Business research methods (4th ed.). Maidenhead: McGraw Hill.

Bonikowski, B. (2016). Nationalism in settled times. Annual Review of Sociology, 42, 427-449. https://doi.org/10.1146/annurev-soc$081715-074412$

Breeze, B. (2013). How donors choose charities: The role of personal taste and experiences in giving decisions. Voluntary Sector Review, 4(2), 165-183. https://doi.org/10.1332/ $204080513 \times 667792$.

Brooks, A. C. (2004). The effects of public policy on private charity. Administration and Society, 36(2), 166-185. https://doi.org/10. 1177/0095399704263474.

Burgoyne, C., Young, B., \& Walker, C. M. (2005). Deciding to give to charity: A focus group study in the context of the household economy. Journal of Community and Applied Social Psychology, 15(5), 383-405. https://doi.org/10.1002/casp.832

Carpenter, J. M., Moore, M., Alexander, N., \& Doherty, A. M. (2013). Consumer demographics, ethnocentrism, cultural values, and acculturation to the global consumer culture: A retail perspective. Journal of Marketing Management, 29(3/4), 271-291. https://doi.org/10.1080/0267257X.2013.766629.

Casale, D., \& Baumann, A. (2015). Who gives to international causes? A sociodemographic analysis of US donors. Nonprofit and Voluntary Sector Quarterly, 44(1), 98-122. https://doi.org/ 10.1177/0899764013507141.
Charities Aid Foundation. (2017). An overview of charitable giving in the UK. Available at: https://www.cafonline.org/docs/defaultsource/about-us-publications/caf-uk-giving-web.pdf. Accessed 3 Feb 2018.

Cheung, C. K., \& Chan, C. M. (2000). Social-cognitive factors of donating money to charity, with special attention to an international relief organization. Evaluation and Program Planning, 23(2), 241-253. https://doi.org/10.1016/S0149-7189(00)000033.

Churchill, G. A. (1979). A paradigm for developing better measures of marketing constructs. Journal of Marketing Research, 1, 64-73. https://doi.org/10.2307/3150876.

Cleveland, M., Laroche, M., \& Papadopoulos, N. (2009). Cosmopolitanism, consumer ethnocentrism, and materialism: An eightcountry study of antecedents and outcomes. Journal of International Marketing, 17(1), 116-146. https://doi.org/10.1509/jimk. 17.1.116.

Crowson, H. M. (2009). Nationalism, internationalism, and perceived UN irrelevance: Mediators of relationships between authoritarianism and support for military aggression as part of the war on terror. Journal of Applied Social Psychology, 39(5), 1137-1162. https://doi.org/10.1111/j.1559-1816.2009.00475.x.

Dalton, S., Madden, H., Chamberlain, S., Carr, S., \& Lyons, C. (2008). 'It's gotten a bit old, charity': Young adults in New Zealand talk about poverty, charitable giving and aid appeals. Journal of Community and Applied Social Psychology, 18(5), 492-504. https://doi.org/10.1002/casp.966.

Dekker, H., Malova, D., \& Hoogendoorn, S. (2003). Nationalism and its explanations. Political Psychology, 24(2), 345-376. https:// doi.org/10.1111/0162-895x.00331.

Delanty, G. (2014). The prospects of cosmopolitanism and the possibility of global justice. Journal of Sociology, 50(2), 213-228. https://doi.org/10.1177/1440783313508478.

Department for Home Security. (2018). Immigration data and statistics. Available at: https://www.dhs.gov/immigration-statis tics. Accessed 10 Jan 2019.

Einolf, C. J., Philbrick, D. M., \& Slay, K. (2013). National giving campaigns in the United States: Entertainment, empathy, and the national peer group. Nonprofit and Voluntary Sector Quarterly, 42(2), 241-261. https://doi.org/10.1177/0899764012467230.

Electoral Commission. (2018). EU referendum results. Available at: https://www.electoralcommission.org.uk/find-information-by-sub ject/elections-andreferendums/past-elections-and-referendums/eureferendum/electorate-and-countinformation. Accessed $12 \mathrm{Feb}$ 2018.

Federico, C. M., Golec, A., \& Dial, J. L. (2005). The relationships between the need for closure and support for military action against Iraq: Moderating effects of national attachment. Personality and Social Psychology Bulletin, 31, 621-632. https://doi. org/10.1177/0146167204271588.

Fernández-Ferrín, P., Bande-Vilela, B., Klein, J. G., \& del RíoAraújo, M. L. (2015). Consumer ethnocentrism and consumer animosity: Antecedents and consequences. International Journal of Emerging Markets, 10(1), 73-88. https://doi.org/10.1108/ ijoem-11-2011-0102.

Fischer, P. M., \& Zeugner-Roth, K. P. (2017). Disentangling countryof-origin effects: The interplay of product ethnicity, national identity, and consumer ethnocentrism. Marketing Letters, 28(2), 189-204. https://doi.org/10.1007/s11002-016-9400-7.

Flatters, P., \& Willmott, M. (2009). Understanding the post-recession consumer. Harvard Business Review, 87(7/8), 106-112.

Glasford, D. E., \& Dovidio, J. F. (2011). E pluribus unum: Dual identity and minority group members' motivation to engage in contact, as well as social change. Journal of Experimental Social Psychology, 47(5), 1021-1024. https://doi.org/10.1016/j.jesp. 2011.03.021. 
Grau, S. L., \& Folse, J. A. G. (2007). Cause-related marketing (CRM): The influence of donation proximity and messageframing cues on the less-involved consumer. Journal of Advertising, 36(4), 19-33. https://doi.org/10.2753/joa00913367360402 .

Hair, J. F., Black, W. C., Babin, B. J., \& Anderson, R. E. (2010). Multivariate data analysis: A global perspective (7th ed.). Upper Saddle River, NJ: Pearson Education.

Hall, D., Jones, S. C., Andrews, K., \& Cridland, L. (2013). Community perceptions of and suggested fundraising strategies for local charities. In R. Brodie (Ed.), ANZMAC 2013 conference proceedings (pp. 1-7). New Zealand: University of Auckland.

Hart, D. J. (2016). Charity begins at home? Setting a future research agenda for national identity and charitable ethnocentrism. Social Business, 6(2), 125-151. https://doi.org/10.1362/ $204440816 x 14715138381621$.

Havens, J. J., O'Herlihy, M. A., \& Schervish, P. G. (2006). Charitable giving: How much, by whom, to what, and how? In W. P. Powell \& R. Steinberg (Eds.), The non-profit sector: A research handbook (2nd ed., pp. 542-567). New Haven: Yale University Press.

Huddy, L., \& Khatib, N. (2007). American patriotism, national identity, and political involvement. American Journal of Political Science, 51(1), 63-77. https://doi.org/10.1111/j.1540-5907. 2007.00237.x

IFAD. (2018). Sending money home: Contributing to the SDGs, one family at a time. Available at: https://www.ifad.org/web/knowl edge/publication/asset/39407416. Accessed 15 Jan 2019.

Jacobson, J. (1997). Religion and ethnicity: Dual and alternative sources of identity among young British Pakistanis. Ethnic and Racial Studies, 20(2), 238-256. https://doi.org/10.1080/ 01419870.1997.9993960.

Kashif, M., Sarifuddin, S., \& Hassan, A. (2015). Charity donation: Intentions and behaviour. Marketing Intelligence \& Planning, 33(1), 90-102. https://doi.org/10.1108/MIP-07-2013-0110.

Kemmelmeier, M., \& Winter, D. G. (2008). Sowing patriotism, but reaping nationalism? Consequences of exposure to the American flag. Political Psychology, 29(6), 859-879. https://doi.org/10. 1111/j.1467-9221.2008.00670.x.

Knowles, S., \& Sullivan, T. (2017). Does charity begin at home or overseas?. Nonprofit and Voluntary Sector Quarterly, 46(5), 944-962. https://doi.org/10.1177/0899764017703710.

Knowles, S. R., Hyde, M. K., \& White, K. M. (2012). Predictors of young people's charitable intentions to donate money: An extended theory of planned behavior perspective. Journal of Applied Social Psychology, 42(9), 2096-2110. https://doi.org/10. 1111/j.1559-1816.2012.00932.x.

Kosterman, R., \& Feshbach, S. (1989). Toward a measure of patriotic and nationalistic attitudes. Political Psychology, 10(2), 257-274. https://doi.org/10.2307/3791647.

Lee, W. N., Hong, J. Y., \& Lee, S. J. (2003). Communicating with American consumers in the post 9/11 climate: An empirical investigation of consumer ethnocentrism in the United States. International Journal of Advertising, 22(4), 487-510. https://doi. org/10.1080/02650487.2003.11072865.

Leslie, L. M., Snyder, M., \& Glomb, T. M. (2013). Who gives? Multilevel effects of gender and ethnicity on workplace charitable giving. Journal of Applied Psychology, 98(1), 49.

Livi, S., Leone, L., Falgares, G., \& Lombardo, F. (2014). Values, ideological attitudes and patriotism. Personality and Individual Differences, 64, 141-146. https://doi.org/10.1016/j.paid.2014.02. 040 .

Lwin, M., Phau, I., \& Lim, A. (2014). An investigation of the characteristics of australian charitable donors. Journal of Nonprofit \& Public Sector Marketing, 26(4), 372-389. https://doi. org/10.1080/10495142.2014.965074.
Mainardes, E. W., Laurett, R., Degasperi, N. C. P., \& Lasso, S. V. (2016). What motivates an individual to make donations of money and/or goods? International Review on Public and Nonprofit Marketing, 13(1), 81-99. https://doi.org/10.1007/ s12208-015-0145-4.

Micklewright, J., \& Schnepf, S. V. (2009). Who gives charitable donations for overseas development? Journal of Social Policy, 38(02), 317-341. https://doi.org/10.1017/s0047279408002869.

Oberecker, E. M., Riefler, P., \& Diamantopoulos, A. (2008). The consumer affinity construct: Conceptualization, qualitative investigation, and research agenda. Journal of International Marketing, 16(3), 23-56. https://doi.org/10.1509/jimk.16.3.23.

Office for National Statistics. (2017). Overview of the UK population. Available at: https://www.ons.gov.uk/peoplepopulationandcom munity/populationandmigration/populationestimates/articles/ overviewoftheukpopulation/july2017. Accessed 16 Dec 2017.

Office for National Statistics. (2018). Migration statistics quarterly report. Available at: https://www.ons.gov.uk/peoplepopulatio nandcommunity/populationandmigration/internationalmigration/ bulletins/migrationstatisticsquarterlyreport/july2018revisedfrom maycoveringtheperiodtodecember2017. Accessed 16 Dec 2017.

Osili, U. O., \& Du, D. (2005). Immigrant assimilation and charitable giving. New Directions for Philanthropic Fundraising, 2005(48), 89-104. https://doi.org/10.1002/pf.108.

Parts, O., \& Vida, I. (2011). The effects of consumer cosmopolitanism on purchase behavior of foreign vs. domestic products. Managing Global Transitions, 9(4), 355. https://doi.org/10.1300/ j097v06n03_06.

Piff, P. K., Kraus, M. W., Côté, S., Cheng, B. H., \& Keltner, D. (2010). Having less, giving more: The influence of social class on prosocial behavior. Journal of Personality and Social Psychology, 99(5), 771. https://doi.org/10.1037/a0020092.

Rajan, S. S., Pink, G. H., \& Dow, W. H. (2009). Sociodemographic and personality characteristics of Canadian donors contributing to international charity. Nonprofit and Voluntary Sector Quarterly, 38(3), 413-440. https://doi.org/10.1177/ 0899764008316056.

Ribar, D. C., \& Wilhelm, M. O. (1995). Charitable contributions to international relief and development. National Tax Journal, 48(2), 229-244.

Rose, S., Spinks, N., \& Canhoto, A. I. (2015). Management research: Applying the principles. Oxon: Routledge.

Rosner, J. L., Li, Y., Chao, M. M., \& Hong, Y. Y. (2010). One world, just a dream? Effects of the Beijing olympic icon on perceived differences between eastern and western culture. Asian Journal of Social Psychology, 13(2), 139-151. https://doi.org/10.1111/j. 1467-839x.2010.01309.x.

Sargeant, A., \& Woodliffe, L. (2007). Gift giving: An interdisciplinary review. International Journal of Nonprofit and Voluntary Sector Marketing, 12(4), 275-307. https://doi.org/10.1002/nvsm. 308.

Schatz, R. T., Staub, E., \& Lavine, H. (1999). On the varieties of National attachment: Blind versus constructive patriotism. Political Psychology, 20(1), 151-174. https://doi.org/10.1111/ 0162-895X.00140.

Schons, L. M., Cadogan, J., \& Tsakona, R. (2015). Should charity begin at home? An empirical investigation of consumers' responses to companies' varying geographic allocations of donation budgets. Journal of Business Ethics. https://doi.org/ 10.1007/s10551-015-2832-9.

Shankarmahesh, M. N. (2006). Consumer ethnocentrism: An integrative review of its antecedents and consequences. International Marketing Review, 10(2), 146-172. https://doi.org/10.1108/ 02651330610660065 . 
Shimp, T. A., \& Sharma, S. (1987). Consumer ethnocentrism: Construction and validation of the CETSCALE. Journal of Marketing Research. https://doi.org/10.2307/3151638.

Shoham, A., Davidow, M., Klein, J. G., \& Ruvio, A. (2006). Animosity on the home front: The Intifada in Israel and its impact on consumer behavior. Journal of International Marketing, 14(3), 92-114. https://doi.org/10.1509/jimk.14.3.92.

Smith, J. R., \& McSweeney, A. (2007). Charitable giving: The effectiveness of a revised theory of planned behaviour model in predicting donating intentions and behaviour. Journal of Community \& Applied Social Psychology, 17(5), 363-386. https:// doi.org/10.1002/casp.906.

Stevenson, C., \& Manning, R. (2010). National identity and international giving: Irish adults' accounts of charitable behaviour. Journal of Community and Applied Social Psychology, 20(4), 249-261. https://doi.org/10.1002/casp.1029.

Strombach, T., Jin, J., Weber, B., Kenning, P., Shen, Q., Ma, Q., et al. (2014). Charity begins at home: Cultural differences in social discounting and generosity. Journal of Behavioral Decision Making, 27(3), 235-245. https://doi.org/10.1002/bdm.1802.

Tabachnick, B. G., \& Fidell, L. S. (2013). Using multivariate statistics (6th ed.). Boston: Pearson.

Taylor, E. J. (1999). The new economics of labour migration and the role of remittances in the migration process. International Migration, 37(1), 63-88. https://doi.org/10.1111/1468-2435. 00066.

Tsai, W. H., Lee, W. N., \& Song, Y. A. (2013). A cross-cultural study of consumer ethnocentrism between China and the US. Journal of International Consumer Marketing, 25(2), 80-93. https://doi. org/10.1080/08961530.2013.759043
Van Hooft, S. (2009). Political patriotism. Journal of Applied Ethics and Philosophy, 1, 20-29.

Wiepking, P. (2010). Democrats support international relief and the upper class donates to art? How opportunity, incentives and confidence affect donations to different types of charitable organizations. Social Science Research, 39(6), 1073-1087. https:// doi.org/10.1016/j.ssresearch.2010.06.005.

Willer, R., Wimer, C., \& Owens, L. A. (2015). What drives the gender gap in charitable giving? Lower empathy leads men to give less to poverty relief. Social Science Research, 52, 83-98. https://doi.org/10.1016/j.ssresearch.2014.12.014.

Yang, Q., Snell, K., \& Tsai, W. S. (2015). Understanding consumer animosity in the politicized global market: From the perspective of young transnational consumers. Journal of International Consumer Marketing, 27(3), 220-236. https://doi.org/10.1080/ 08961530.2014.987418.

Yildiz, H., Heitz-Spahn, S., \& Belaud, L. (2018). Do ethnocentric consumers really buy local products? Journal of Retailing and Consumer Services, 43, 139-148. https://doi.org/10.1016/j.jret conser.2018.03.004.

Zeugner-Roth, K. P., Zabkar, V., \& Diamantopoulos, A. (2015). Consumer ethnocentrism, national identity, and consumer cosmopolitanism as drivers of consumer behaviour: A social identity theory perspective. Journal of International Marketing, 23(2), 25-54. https://doi.org/10.1509/jim.14.0038.

Publisher's Note Springer Nature remains neutral with regard to jurisdictional claims in published maps and institutional affiliations. 